\title{
Pengembangan Aktivitas Wisata di Desa Ciririp
}

\author{
Lice Sari ${ }^{1}$, Nova Irene Bernedeta Sitorus ${ }^{2}$
}

1,2 Tourism Fakulty, Pelita Harapan University, Jakarta Indonesia

lice.sari@uph.edu ${ }^{1}$, nova.sitorus@uph.edu ${ }^{2}$

\begin{abstract}
ABSTRAK
Desa Ciririp berada di Kecamatan Sukasari, Kabupaten purwakarta. Desa ini berada pada ketinggian $116 \mathrm{~m}$ di atas permukaan laut. Desa Ciririp berbatasan dengan Desa Kertamanah di sebelah utara, berbatasan dengan Desa Sukasari di sebelah selatan, berbatasan dengan kawasan Perhutani di sebelah barat dan berbatasan dengan Danau Jatiluhur di sebelah timur. Desa Ciririp memiliki daya tarik wisata alam yang diantaranya danau, hutan, air terjun, sungai dan pemandangan alam yang masih asri. Salah satu daya di desa ini adalah Curug Tilu yang mengalir pada tiga undakan batu dan bongkahan batu andesit. Penulis tertarik untuk membahas tentang pengembangan aktivtias di Desa Ciririp. Dengan berkembangnya aktivitas wisata dapat meningkatkan minta wisatawan untuk mengunjungi Kabupaten Purwakarta, secara khusus ke Desa Ciririp. Penelitian ini menggunakan metode kualitatif dimana peneliti menggunakan instrumen kunci dan objek yang alamiah. Dalam penelitian ini data diperoleh dengan melakukan wawancara mendalam terhadap partisipan kunci. Secara keseluruhan Desa Ciririp belum memanfaatkan sumber daya yang dimiliki secara maksimal, masih terdapat beberapa sumber daya alam yang tidak dikembangkan sebagai daya tarik wisata. Secara keseluruhan Desa Ciririp belum memanfaatkan sumber daya yang dimiliki secara maksimal, masih terdapat beberapa sumber daya alam yang tidak dikembangkan sebagai daya tarik wisata. Diperlukan kolaborasi antara pengelola, masyarakat dan pemerintah dalam mengembangkan aktivitas wisata di Desa Ciririp
\end{abstract}

ARTICLE HISTORY

Submitted:19.06.2021

Revised:08.07.2021

Accepted:09.07.2021

Online first:10.07.2021

\section{KATA KUNCI}

Aktivitas, wisata, desa wisata 


\section{Pendahuluan}

Pariwisata merupakan usaha yang sangat potensial untuk meningkatkan devisa negara. Berdasarkan Undang Undang No. 10 tahun 2009 tentang Kepariwisataan, yang dimaksud dengan pariwisata adalah berbagai macam kegiatan wisata yang didukung oleh berbagai fasilitas serta layanan yang disediakan masyarakat, pengusaha, pemerintah pusat dan pemerintah daerah. Sebagai indikator keberhasilan suatu destinasi pariwisata, komponen produk wisata merupakan hal yang harus dimiliki oleh suatu daerah dalam mengembangkan sektor kepariwisataannya. Ketiga komponen produk wisata yaitu attraction, amenities, dan accessibility menjadi syarat utama untuk dikembangkan dalam menarik minat para wisatawan untuk berkunjung.

Salah satu daerah di Indonesia yang memperoleh dampak positif dari perkembangan kegiatan pariwisata adalah Kabupaten Purwakarta. Kabupaten Purwakarta terletak di Provinsi Jawa Barat yang memiliki beragam daya Tarik wisata baik alam, budaya maupun buatan yang sangat potensial untuk dikembangkan. Kabupaten Purwakarta pada ajang Indonesia Attractiveness Award 2017 memperoleh 3 penghargaan yakni sebagai kabupaten terbaik, sebagai kabupaten terbaik dalam investasi, dan kabupaten potensial infrastruktur. Dengan demikian Kabupaten Purwakarta memiliki potensi dan peluang dalam pengembangan sektor pariwisata.

Kabupaten Purwakarta juga terletak diantara 2 kota besar di Pulau Jawa yaitu Ibukota Jakarta dan Bandung, sehingga Kabupaten ini memiliki peluang yang besar dalam meningkatkan jumlah kunjungan wisatawan. Salah satu upaya pemerintah untuk mengembangkan pariwisata adalah dengan mengembangkan daya tarik wisata di Kabupaten Purwakarta. Upaya lain yang dilakukan oleh pemerintah Kabupaten Purwakarta untuk meningkatkan rata-rata lama tinggal dan mensejahterakan masyarakat adalah dengan mengembangkan desa-desa wisata di Kabupaten Purwakarta.

Desa Ciririp berada di Kecamatan Sukasari, Kabupaten purwakarta. Desa ini berada pada ketinggian $116 \mathrm{~m}$ di atas permukaan laut. Desa Ciririp berbatasan dengan Desa Kertamanah di sebelah utara, berbatasan dengan Desa Sukasari di sebelah selatan, berbatasan dengan kawasan Perhutani di sebelah barat dan berbatasan dengan Danau Jatiluhur di sebelah timur. Desa Ciririp memiliki daya tarik wisata alam yang diantaranya danau, hutan, air terjun, 
sungai dan pemandangan alam yang masih asri. Salah satu daya di desa ini adalah Curug Tilu yang mengalir pada tiga undakan batu dan bongkahan batu andesit.

Aktivitas wisata adalah keseluruhan aktivitas yang terdapat dalam sebuah destinasi dan apa yang dapat dilakukan wisatawan selama kunjungannya. (Stankovic dan Dukic, 2009). Daya tarik wisata merupaka motivator utama bagi wisatawan untuk datang ke satu daerah, namun keberadaan aktivitas wisata yang menarik akan menambah nilai tambah bagi sebuah daya tarik wisata. Menurut Hendee et al dalam Altman Wohlwill (2013:148) aktivitas wisata dikembangkan ke dalam 5 klasifikasi sebagai berikut :

a. Appreciate symbolic

Kegiatan yang termasuk ke dalam kategori ini adalah mengacu pada suatu bentuk apresiasi atau bersifat mengagumi, terutama spresiasi terhadap lingkungan alam seperti photographs, hiking, mountain climbing dan sebagainya.

b. Extractive symbolic

Kegiatan yang termasuk ke dalam kategori ini adalah fishing, hunting dan sebagainya.

c. Passive free play

Kegiatan ini melibatkan keadaan fisik dan bersifat santai seperti sightseeing, entertainment, sunbathing, resting, dan relaxing.

d. Sociable learning

Tujuan dari kegiatan ini adalah tujuan sosial seperti meeting people, shopping, nature study dan sebagainya.

e. Active expensive

Aktivitas wisata ini bersifat aktif dan melibatkan keadaan fisik seperti swimming, boating, canoeing dan sebagainya.

Berdasarakan pemaparan diatas maka penulis tertarik untuk membahas tentang pengembangan aktivtias di Desa Ciririp. Dengan berkembangnya aktivitas wisata dapat meningkatkan minta wisatawan untuk mengunjungi Kabupaten Purwakarta, secara khusus ke Desa Ciririp. 


\section{Kajian Teori}

Aktivitas wisata merupakan keseluruhan aktivitas yang terdapat dalam sebuah destinasi dan apa yang dapat dilakukan wisatawan selama waktu kunjungannya (Stankovic dan Dukic, 2009). Pedoman utama wisawatan dalam mengunjungi daerah tujuan wisata adalah daya tarik wisat dimana dengan adanya aktivitas wisata dapat menambah nilai bagi wisawatan yang akan melakukan sebuah kegiatan wisata. Menurut Mcintosh et al dalam Neverterry (2010:41) aktivitas wisata dapat berupa aktivitas rekreasi, kunjungan, mengunjungi teman atau kerabat, bisnis konvensi, festival, hiburan, belanja dan olahraga. Sedangkan menurut Schmoll dalam Yoeti (2008:120) aktivitas pada sebuah destinasi wisata membutuhkan entertainment, sport, sightseeing, shopping, and visit to museums.

Aktivitas wisata edukasi adalah sebuah program dimana peserta dalam kegiatan wisata bertujuan untuk mendapatkan pengalaman belajar secara langsung terkait dengan lokasi yang sedang dikunjungi (Rodger dalam Munir, 2013:2).

Aktivitas wisata olahraga adalah kegiatan yang memadukan kegiatan olahragad an kegiatan berwisata, kegiatan ini mengharuskan wisawatan untuk aktif bergerak olah tubuh secara langsung. Kegiatan lainnya dapat berupa kegiatan olahraga secara pasif dimana wisatawan tidak melakukan gerak olah tubuh melainkan hanya menjadi penikmat olahraga saja (Ismayanti, 2010). Keberadaan potensi wisata olahraga dalam pengembangan pariwisata berdampak positif terhadap lamanya kunjungan wisawatan dan jumlah wisatawan serta berpengaruh terhadap berbagai sektor seperti ekonomi, jasa, transportasi dan industri pariwisata (Astuti, M.T, 2015:40).

Aktivitas hiburan merupakan elemen penting bagi wisata yang dapat memberikan peningkatan daya tarik destinasi serta menjadi peluang bisnis lokal, meningkatkan daya saing destinasi dan loyalitas wisatawan (Gowreesunkar, 2014:2). Wisata belanja merupakan kegiatan insidensial wisawatan untuk pembelian produk pada destinasi wisata (Yu dan Litrell dalam Choi et al, 2015:3), aktivitas wisata belanja juga telah menjadi salah satu penyumbang dalam jumlah besar dari pengeluaran wisatawan (Choi et al, 2015:1). 


\section{Metode Penelitian}

Penelitian ini menggunakan metode kualitatif dimana peneliti menggunakan instrumen kunci dan objek yang alamiah. Suatu objek yang alamiah merupakan objek yang tidak dapat dimanipulasi oleh peneliti dan bersifat apa adanya, sehingga peneliti keluar dari objek kondisinya yang relatif tidak berubah. Objek penelitian merupakan sasaran ilmiah dalam mendapatkan data dengan tujuan dan kegunaan tertentu tentang sesuatu hal objektif, valid dan reliable (Sugiyono, 2013:1-2). Objek penelitian ini berfokus pada berbagai aktivitas wisata di Desa Ciririp yang dapat mendukung pariwisat berkelanjutan.

Menurut Lexy J.Moleong (2007:6) menyatakan bahwa penelitian kualitatif merupakan penelitian yang bersifat holistik dan bahasa yang bertujuan mendiskripsikan suatu konteks khusus yang alamiah dalam bentuk kata-kata dan bahasa yang bertujuan untuk memberikan pemahaman mengenai fenomena apa yang dialami oleh subjek penelitian seperti perilaku, persepsi, motivasi,tindakan dan lain-lain dengan memanfaatkan berbagai metode ilmiah.

Dalam penelitian ini data diperoleh dengan melakukan wawancara mendalam terhadap partisipan kunci. Wawancara merupakan pertemuan dua orang melalui suatu tanya jawab yang bertujuan saling memberikan informasi yang selanjutnya dapat dikonstruksikan makna yang terdapat di dalam suatu topik tertentu (Sugiyono, 2013). Adapun partisipan adalah orang pada latar belakang penelitian yang memberikan suatu informasi mengenai situasi dan kondisi latar belakang penelitian (Moleong, 2010:132). Dalam penelitian ini yang menjadi partisipan kunci adalah Staf dari Dinas Pariwisata Kabupaten Purwakarta dann kelompok penggerak wisata di Desa Ciririp.

\section{Hasil dan Pembahasan}

Aktivitas wisata yang berada di Desa Ciririp memiliki keunikan tersendiri jika dibandingkan dengan desa-desa lainnya di Kabupaten Purwakarta. Aktivitas wisata di desa ini mengarah kepada wisata edukasi, salah satunya adalah pembelajaran budidaya ikan, dimana mayoritas penduduk memiliki mata pencaharian sebagai nelayan. Wisatawan yang berkunjung mendapatkan pembelajaran mengenai budidadaya ikan tawar. Wisatawan tidak hanya dapat melihat berbagai jenis ikan tawar tetapi juga dapat belajar bagaimana mengelola hasil perikanan dan budidayanya. Disamping wisata edukasi, Desa Ciririp juga menawarkan 
aktivitas wisata olahraga berupa hiking di Gunung Haur dengan ketinggian 517 MDPL, dengan ketinggian tersebut wisatawan yang masih pemula dalam aktivitas hiking tetap bisa menikmatinya. Gunung Haur memiliki Puncak Kirarangge dan Puncak Batu. Untuk menuju puncak tersebut, pengunjung harus melalui sebuah tanjakan yang disebut Tanjakan Turdo yang merupakan tanjakan terjal. Rata-rata waktu yang di habiskan pendaki untuk mencapai dan menikmati Gunung Haur adalah 2- 3 jam.

Aktivitas wisata lainnya yang ada di Desa Ciririp adalah kesenian yang menggunakan alat musik yang berasal dari bambu seperti Calung dan Karinding. Alat music tersebut dibuat langsung oleh masyarakat setempat karena banyaknya tanaman bambu di Desa Ciririp. Wisatawan yang datang ke Desa Ciririp akan disajikan pertunjukan music tradisional Desa Ciririp dengan menggunakan alat musik Calung dan Karinding. Aktivitas wisata lainnya yang terdapat di Desa Ciririp adalah menikmati kuliner ikan bakar khas Desa Ciririp. Tidak hanya menikmati ikan bakar, wisatawan yang berkunjung ke desa ini juga dapat membawa pulang madu hutan murni sebagai oleh-oleh khas Desa Ciririp.

Aktivitas masyarakat yang dapat mendukung pariwisata di Desa Ciririp adalah hasil kerajinan bambu yang dihasilkan oleh masyarakat/pengrajin bamboo karena des aini merupakan salah satu penghasil bamboo hitam. Kreasi yang dihasilkan dengan menggunakan bamboo hitam tersebut adalah gelas, teko, celengan, dan lain-lain. Keterampilan dalam membuat kreasi bambu ini hanya dapat dilakukan oleh kelompok kecil di Desa Ciririp. Selain kreasi bambu, keterampilan lain yang dimiliki oleh masyarakat di Desa Ciririp adalah mengolah gadung (umbi beracun) menjadi keripik khas Desa Ciririp. Tidak semua bisa mengolah gadung (umbi beracun) menjadi makanan (keripik) sehingga hal ini dapat menjadi oleh-oleh khas di Desa Ciririp.

Aktivitas budaya yang ada di Desa Ciririp adalah masih menggunakan alat tradisional dalam menangkap ikan seperti jaring. Masyarakat sepakat untuk menggunakan cara dan alat tradisional demi menjaga lingkungan dan kearifan lokal di Desa Ciririp. Budaya lokal yang masih dipercaya di Desa Ciririp adalah adanya hutan larangan yang yang dipercaya masih memiliki hal unik didalamnya. Hutan larangan tersbut adalah Hutan Pasarean dimana 
didalamnya terdapat kuburan yang isinya benda-benda pusaka leluhur. Dipercaya bahwa jika ada orang yang memiliki niat tidak baik dan mengambil peninggalan leluhur tersebut, akan mendapat musibah didalam perjalanan. Kepercayaan ini dipelihara secara turun temurun guna melestarikan budaya dan menanamkan kepada masyarakat dan pengunjung untuk menghindari niat jahat yang dapat berdampak buruk bagi mereka. Aktivitas budaya juga dapat dinikmati melalui bangunan tempat tinggal di Desa Ciririp yang memiliki keunikan yaitu berbentuk panggung (arsitektur Sunda). Bentuk bangunan ini berbentuk Julang Ngapak dan diatasnya terdapat capit gunting atau dibagian atasnya dibuat bercabang seperti gunting yang akan menjepit.

Tabel 1. Pengembangan Aktivitas Wisata di Desa Ciririp

\begin{tabular}{|c|c|}
\hline Aktivitas Wisata & Pengembangan Aktivitas Wisata \\
\hline $\begin{array}{l}\text { Wisata edukasi budidaya } \\
\text { ikan tawar }\end{array}$ & $\begin{array}{l}\text { Membuat paket wisata edukasi agar dapat } \\
\text { memasarkannya melalui nernagai platform sosial } \\
\text { media. }\end{array}$ \\
\hline hiking & $\begin{array}{l}\text { Membuat loket/pos informasi bagi pengunjung } \\
\text { yang ingin melakukan hiking dan memberikan } \\
\text { pelatihan bagi pemandu. }\end{array}$ \\
\hline $\begin{array}{l}\text { Berbelanja kerajinan } \\
\text { berbahan bambu hitam }\end{array}$ & $\begin{array}{l}\text { Membuat kemasan yang menarik dan } \\
\text { standarisasinya sehingga dapat dipasarkan juga di } \\
\text { luar Desa Ciririp. }\end{array}$ \\
\hline Berbelanja madu & $\begin{array}{l}\text { Membuat kemasan yang menarik dan } \\
\text { memasarkannya bagi pengunjung atau keluar } \\
\text { Desa Ciririp. }\end{array}$ \\
\hline $\begin{array}{l}\text { Berbelanja keripik berbahan } \\
\text { gadung }\end{array}$ & $\begin{array}{l}\text { Membuat kemasan yang menarik dan membuat } \\
\text { story telling yang menarik dibalik pembuatan } \\
\text { keripik gadung dimana tidak semua dapat } \\
\text { mengolah umbi beracun yang digunakan sebagai } \\
\text { bahan utama keripik. }\end{array}$ \\
\hline Tur menuju hutan larangan & $\begin{array}{l}\text { Membuat paket tur dan melatih pemandu dalam } \\
\text { menyampaikan keunikan cerita di hutan larangan. }\end{array}$ \\
\hline $\begin{array}{l}\text { Menginap di homestay } \\
\text { /rumah penduduk }\end{array}$ & $\begin{array}{l}\text { Memberikan pelatihan dalam mengelola dan } \\
\text { memasarkan homestay. }\end{array}$ \\
\hline
\end{tabular}

Secara keseluruhan Desa Ciririp belum memanfaatkan sumber daya yang dimiliki secara maksimal, masih terdapat beberapa sumber daya alam yang tidak dikembangkan sebagai daya tarik wisata. Diperlukan kolaborasi antara pengelola, masyarakat dan pemerintah dalam mengembangkan aktivitas wisata di Desa Ciririp. Pengembangan adalah sebuah kegiatan 
yang sudah direncanakan untuk perubahan yang signifikan. Berdasarkan data yang didapat, pengembangan aktivitas wisata di Desa Ciririp belum maksimal sehingga perlu banyak dukungan baik dari pengelola, masyarakat maupun pemerintah. Dari sudut pandang masyarakat dan pengelola dapt berkolaborasi dalam membuat dan mengaktifkan pokdarwis yang dapat mengelola dan menjadi aspirasi dalam pengembangan aktivitas wisata di Desa Ciririp. Sedangkan dari sudut pandang pemerintah dapat lebih memfasilitasi masyarakat baik dalam pelatihan maupun dukungan pengembangan aktivitas wisata di Desa Ciririp. Dengan demikian Desa Ciririp dapat lebih layak dikunjungi dan meningkatkan minat pengunjung.

\section{Kesimpulan}

Berdasarkan data yang didapat, pengembangan aktivitas wisata di Desa Ciririp belum maksimal sehingga perlu banyak dukungan baik dari pengelola, masyarakat maupun pemerintah. Dari sudut pandang masyarakat dan pengelola dapt berkolaborasi dalam membuat dan mengaktifkan pokdarwis yang dapat mengelola dan menjadi aspirasi dalam pengembangan aktivitas wisata di Desa Ciririp. Sedangkan dari sudut pandang pemerintah dapat lebih memfasilitasi masyarakat baik dalam pelatihan maupun dukungan pengembangan aktivitas wisata di Desa Ciririp. Dengan demikian Desa Ciririp dapat lebih layak dikunjungi dan meningkatkan minat pengunjung. 


\section{Author's declaration}

\section{Authors' contributions and responsibilities}

$\sqrt{ }$ The authors made substantial contributions to the conception and design of the study.

$\sqrt{ }$ The authors took responsibility for data analysis, interpretation and discussion of results.

$\sqrt{ }$ The authors read and approved the final manuscript.

\section{Availability of data and materials}

$\sqrt{ }$ All data are available from the authors.

\section{Competing interests}

$\sqrt{ }$ The authors declare no competing interest. 


\section{Referensi}

1) Altman, Irwin \& Wohlwill, Joachim. (2013). Human Behavior and Environment Advances in Theory and Research. Volume 1. New York: Springer \& Business Media

2) Astuti, M,T. (2015). Potensi Wisata Olah Raga Dalam Meningkatkan Kunjungan Wisatawan. Jurnal Kepariwisataan Indonesia. Vol.10(1), 31-40

3) Choi, Ju, Mi et al. (2015). Progress in Shopping Tourism. Journal of Travel \& Tourism Marketing, 1-24.

4) Gowreesunkar, v, b. (2014). Entertainment of leisure tourists in island destinatios: evidence from the island of Mauritius. African journal of hospitality tourism and leisure. Vol.4,1-19.

5) Ismayanti. 2010 . Pengantar Pariwisata. Jakarta:Grasindo.

6) Munir. (2013). Managing Educational Tourism. Bandung: UPI Bandung

7) Neverterry, Rosse. 2010. Pariwisata Berbasis Masyarakat Dalam Pengelolaan Wisata Petualangan Arung Jeram di Sungai Citarik Kabupaten Sukabumi. Bandung:STPB.

8) Stankovic, Ljiljanad an Suzana, Dukic. (2009). Challenges of Strategic Marketing of Tourist Destination Under The Crisis Condiitions. Facta Universitatis. Economics and Organization vol 6(1), 23-31

9) Sugiyono. (2013). Metode Penelitian Kuantitatif, Kualitatif dan RED. Bandung:Alfabeta

10) Yoeti, Oka A. (2008). Perencanaan dan Pengembangan Pariwisata. Jakarta:PT.Pradaya Paramita. 